\title{
IS LINDHOLMIOLA CORCYRENSIS (ROSSMÄSSLER, 1838) (MOLLUSCA: GASTROPODA) EXTINCT IN CROATIA?
}

\author{
VESNA ŠTAMOL \\ Croatian Natural History Museum, Demetrova 1, 10000 Zagreb, Croatia
}

\begin{abstract}
Štamol, V.: Is Lindholmiola corcyrensis (Rossmässler, 1838) (Mollusca: Gastropoda) extinct in Croatia? Nat. Croat., Vol. 25, No. 1, 159-162, 2016, Zagreb.

This paper discusses the reliability of data on finding localities of the land snail Lindholmiola corcyrensis (Rossmässler, 1838) in Croatia and concludes that this species has probably never inhabited and probably does not inhabit Croatia.
\end{abstract}

Key words: land snails, Lindholmiola corcyrensis, Croatia

Štamol, V.: Lindholmiola corcyrensis (Rossmässler, 1838) (Mollusca: Gastropoda) izumrla u Hrvatskoj? Nat. Croat., Vol. 25, No. 1, 159-162, 2016, Zagreb.

Raspravljena je pouzdanost podataka o nalazištima vrste kopnenog puža Lindholmiola corcyrensis (Rossmässler, 1838) u Hrvatskoj, te je zaključeno da ta vrsta u njoj najvjerojatnije nije obitavala niti obitava.

Ključne riječi: kopneni puževi, Lindholmiola corcyrensis, Hrvatska

The malacologists Peter Subai and Eike Neubert recently published a very important paper (Subai \& NeuberT, 2014), providing a comprehensive look at the terrestrial snails of the genus Lindholmiola. All the statements given about the conchiological characteristics, genital structures, synonyms and distribution maps emerged exclusively from the authors' study of an impressive number of specimens from significant private and museum collections. Accordingly, we find that the only species of the genus Lindholmiola found in Croatia is L. corcyrensis (Rossmässler, 1838), with three localities. The paper lists the coordinates of two of these localities (both in southern Dalmatia: Prapratna Bay on the Pelješac Peninsula, and the islet Badija near the island of Korčula). In both cases, the specimens were washed ashore (Subai \& Neubert, 2014: 46). The third locality at "Zirona grande" is not listed as being washed ashore; however, the authors did not find a corresponding present day toponym and therefore were unable to determine its coordinates (Subai \& Neubert, 2014: 46) or display it on the distribution map (Subai \& Neubert, 2014: 56, Fig. 29). The mentioned distribution map of Lindholmiola corcyrensis adds the two stated localities from Croatia alongside localities in Greece, Albania, Montenegro and Italy, thereby creating the impression that the Croatian localities are sites of the actual distribution of the species. However, as these were sea deposits, this is not the case. It has been emphasized on many occasions (for example BrusinA, 1872: 150; 1881: 382; ŠтAмоL et al., 2015: 337) that the permanent sea currents that flow along the eastern Adriatic coast from south to north, and the strong southern winds, bring floating material from the southern seas into more northern areas, where they get deposited on the shores. These authors also pointed out that for these reasons, some species, such as 
Triloba sandri (Küster, 1844), were described on the basis of alluvial specimens, while the actual site of inhabitation was in another country, which was occasionally not discovered until decades later (ŠTAmol et al., 2015). For that reason, it is necessary to map sites the only evidence for which is individuals that have been washed up differently than the "real" localities, or perhaps even to omit them. Otherwise, the existence of uniform markings on a map will claim equal validity for each site. Even Subai \& Neubert (2014: 56) unified the significance of all "localities" by stating that there are two isolated sites in Croatia, which are approximately $200 \mathrm{~km}$ north of the nearest recorded sites, and they later conclude that these species „once could be found along the Dalmatian coast northwards to the delta of the Neretva River" and that "All these populations have to be considered extinct" (SubAi \& Neubert, 2014: 89). As for the the third Croatian locality listed in Subai \& Neubert (2014: 89) "Zirona grande", this is a toponym that was used in works from the $19^{\text {th }}$ and the beginning of the 20th century for the central Dalmatian island Drvenik Veli, situated north of the island of Šolta. Given this terminology, it can be assumed that the two specimens of Lindholmiola corcyrensis from the Senckenberg Museum examined by Subai and Neubert date back to this period. Since notes about material having been washed up were rarely made in those times, there is the possibility that these two specimens were deposited on shore, although this was not noted on the label in the collection. If we accept the doubt about the specimens being washed up at the locality "Zirona grande", according to the data given by Subai \& Neubert (2014), it should be stressed that there is no evidence that living populations of this species ever existed at Croatian localities. For that reason, it is bold to say the least and in any case erroneous to conclude on the basis of the said data that the populations of Lindholmiola corcyrensis have gone extinct at those localities. In general, the incorrect claims of the species distribution range and the disappearance of its population, have led to the unjustified inclusion of this species on the red lists of certain countries, and incorrect assessments of the threat to the species in Europe.

Regardless of the fact that Subai \& Neubert (2014) by not taking into account the literature data on the localities for material they could not verify, ignored the issue of the impact made by literature records of incorrectly determined specimens on the knowledge of species distribution, I believe that it is not wrong to consider them as potential localities. Lindholmiola corcyrensis has been recorded in Croatia in a few malacological papers, though over a long time interval, from the earliest publications to the present day, on a truly wide area of the Croatian eastern Adriatic coast from the southernmost to the northern areas, with the exception of the northernmost parts. In the alluvial sea deposits, it is listed for the island of Lokrum (Cusmich, 1858: 91; SubAi \& Neubert, 2014: 46), for the wide Dubrovnik area, including the island of Lokrum (BRusina, 1872: 150), for the island of Mljet (Reischütz \& Reischütz, 2000: 64), Pelješac peninsula (MaAssen, 2005: 53; Subai \& Neubert, 2014: 46) and Dugi otok (ŠTAmol, 2004: 106; ŠTAMOL \& KLeTEČKI, 2005: 19). As previously explained, since it is unjustifiable to equate marine deposits with actual species distribution, these localities cannot be considered evidence of the presence of the species in Croatia, i.e. at these localities.

There are also papers about the Croatian localities of L. corcyrensis which do not refer to whether these are part of washed-up deposits or not. These are, from south to north, the island of Lokrum (Brusina, 1866: [121]), Dubrovnik (Bielz, 1865: 179; Strobel, 1854: 116), island of Hvar (Westerlund, 1889: 19; 1890: 20; Bielz, 1865: 179; Kobelt, 1897: 310; Strobel, 1854: 116), island of Drvenik Veli (Küster, 1842: 301, Subai \& Neubert, 2014), island of Kornat (Strobel, 1854: 116; Bielz, 1865: 179), island of Vele Orjule near the island of Lošinj (FrANK, 1991: 373). As explained, in the collections and papers from the 
$19^{\text {th }}$ and turn of the 20th century, it was not common practice to make reference to deposits that had been washed up, and therefore the sources of these data, including newer works based on them, cannot be considered a foundation for knowledge of the species distribution. Only one paper (FrANK, 1991: 373), i.e. data source coming from the time period of these "uncertain” reports, could testify to the contrary. Based on the words of Christa Frank (pers. com., 2015), the few found specimens were definitely not alive, and were „in all probability washed ashore by the sea”.

I believe that the reports for the former Dalmatia region (SCHRÖCKINGER-NEUDENBERG, 1865: 315; Frauenfeld, 1856: 446; Brusina, 1874: 185; Stalio, 1876: 2), which today does not fully fall within the Croatian territory, and for the Neretva River (AnONymous, 1846: 436; Strobel, 1854: 116; Bielz, 1865: 179), which does not flow only through Croatia, cannot be evidence of the presence of this species in Croatia. Based only on the literature data BANK $(2007,2010,2013)$ and ŠTAMOL (2010) report this species for Croatia. Suspicions concerning the existence of L. corcyrensis were expressed by KoвeLt $(1897: 310)$ for the island of Hvar, by ŠтAмоL et al. (2012: 448) for the island of Kornat and for the whole of Croatia (ŠTAMol et al., 2012: 448). BRUsina (1872: 150) is convinced that L. corcyrensis does not inhabit Croatia. The non-existence of species in a given area is a claim that it is very difficult or virtually impossible to prove. However, on the basis of recent faunistic research along the eastern Adriatic coast in Croatia, in which no living specimens of L. corcyrensis were found in Croatia (MAAssen, 1978, 1979; 2005, 2005a; Štamol, 1986, 2004, 2013; ŠTAMol \& Velkovrh, 1995; Štamol \& Poje, 1998; Reischütz \& Reischütz; 1999, 2000, 2002, 2005; Fischer et al., 2000; ReischüTZ et al., 2002; ŠTAMOL \& KLETEČKI, 2005; ŠTAMOL et al., 2012), I am inclined to the opinion that this species does not inhabit Croatia. This is the main reason why this species was not included in the Red List of Land Snails of Croatia (LAJTNER et al., 2013). Future research should be directed at confirming or rejecting this statement.

Received April 7, 2016

\section{REFERENCES:}

Anonymous, 1846: Conchiliologia. La Dalmazia 2 (41), 434-436.

Bank, R. A., (ed.) 2007: Mollusca, Gastropoda. Fauna Europaea version, 1.3, http://www.faunaeur.org/.

BANK, R. A., 2010: Fauna europaea project. Checklist of species-group taxa of the continental Mollusca (excl. Bivalvia) living in Albania and former Yugoslavia, Manuscript, updated by Ruud A. Bank, 25-12-2010.

BANK, R. A., (ed.) 2013: Mollusca, Gastropoda. Fauna Europaea version, 2.6.2, http://www.faunaeur.org/

BiElz, E. A., 1865: Systematisches Verzeichniss der Land- und Süsswasser-Mollusken des österreichischen Kaiserstaates. Verh. Mitt. siebenbürg. Ver. Naturw. Hermannstadt 16, 173-186.

Brusina, S., 1866: Contribuzione pella Fauna dei molluschi dalmati. Verh. k. k. zool. bot. Ges. Wien 16, Beilage, 1-134.

BRUsinA, S., 1872: Naravoslovne crtice sa sjevero-istočne obale jadranskoga mora, sabrao god. 1868 i 1871. Dio prvi. Rad JAZU 19, 105-177.

BRusinA, S., 1874: Naravoslovne crtice sa sjevero-istočne obale jadranskoga mora sabrao god. 1873. Dio drugi. Rad JAZU 27, 131-193.

BrusinA, S., 1881: I. E. Kuzmić. Vienac zabavi i pouci 13 (20-24), 382.

Cusmich, G., 1858: Elenco nominale degli oggetti di Storia naturale, donati sulla fine dell anno scolastico prossimo decorso al Gabinetto ginnasiale dal Molto Reverendo Padre Maestro in farmacia Giov. Evangelista Cuzmich, dei quali nel programma dell anno passato esibile semplicemente le indicazioni numeriche sommarie. p. 85-107.

Fischer, W., Kittel, K., Reischütz, A. \& Reischütz, P. L., 2000: Ein Beitrag zur Kenntnis der Molluskenfauna von Pag (Nord-Dalmatien, Kroatien). Nachrichtenbl. Ersten Vorarlberger Malak. Ges. 8, 53-59.

FRANK, CH., 1991: Über Molluskenfunde aus Jugoslawien und den der Küste vorgelagerten Inseln des adriatischen Meeres. Zeitschr. angew. Zool. 78 (3), 349-380.

Frauenfeld, G., 1856: Beitrag zur Fauna Dalmatien`s. Verh. zool. bot. Ver. Wien 6, 431-448. 
КовеLт, W., 1897: Studien zur Zoogeographie. Die Mollusken der palaearktischen Region. VIII+344 pp. C. W. Kreidel`s Verlag, Wiesbaden.

Küster, H. C., 1842: Reiseberichte aus Dalmatien und Montenegro. Isis von Oken 1842 (4), 283-301.

LaJTNER, J., ŠtAMOL, V. \& SLAPNIK, R., 2013: Crveni popis kopnenih i slatkovodnih puževa Hrvatske. Emys, Zagreb (http://www.dzzp.hr/vrste/crveni-popis-biljaka-i-zivotinja-rh/crveni-popis-biljaka-i-zivotinjarepublike-hrvatske-146.html)

MaAssen, W. J. M., 1978: Malakologische aantekeningen uit Joegoeslavië: Omis aan de Cetina. De Kreukel $14(6), 61-66$.

MaAssen, W. J. M., 1979: Malakologische aantekeningen uit Joegoeslavië: Peljesac en Korcula. De Kreukel $15(5 / 6), 45-48$.

MAASSEN, W. J. M., 2005: Malakologische aantekeningen uit Joegoslavië: nogmaals enkele opmerkingen over de terrestrische mollusken van het schiereilend Peljesac. De Kreukel 41 (5/6), 47-58.

MaAssen, W. J. M., 2005a: Malakologische aantekeningen uit Joegoslavië: vondsten van niet-mareine mollusken van het eiland Krk. De Kreukel 41 (7), 77-82.

Reischüтz, A. \& Reischüтz, P. L., 1999: Ein Beitrag zur Kenntnis der Molluskenfauna der Insel Vis (Mitteldalmatien, Kroatien). Nachrichtenbl. Ersten Vorarlberger Malak. Ges. 7, 35-39.

Reıschüтz, A. \& Reischüтz, P. L., 2000: Ein Beitrag zur Kenntnis der Molluskenfauna der Insel Mljet (Dalmatien, Kroatien). Nachrichtenbl. Ersten Vorarlberger Malak. Ges. 8, 60-65.

Reischüтz, A. \& Reischüтz, P. L., 2002: Ein Beitrag zur Kenntnis der Molluskenfauna von Konavle (Süddalmatien, Kroatien). Nachrichtenbl. Ersten Vorarlberger Malak. Ges. 10, 47-51.

Reischüтz, A. \& Reischüтz, P. L., 2005: Nochmals zur Molluskenfauna der Insel Pag (Nord-Dalmatien, Kroatien). Nachrichtenbl. Ersten Vorarlberger Malak. Ges. 13, 56.

Reischütz, A. \& Reischütz, P. L., Fischer, W., Fraberger, U., Kiennast, H., 2002: Ein Beitrag zur Kenntnis der Molluskenfauna von Korcula (Dalmatien, Kroatien). Nachrichtenbl. Ersten Vorarlberger Malak. Ges. 10, 52-58.

SchröCKInger-Neudenberg, J. R., 1865: Oesterreichs gehäusetragende Bauchfüsser und Muschelthiere. Eine systematische Aufzählung. Verh. zool.-bot. Ges. Wien 15, 303-324.

Stalio, L., 1876: Catalogo sistematico delle conchiglie terrestri e fluviatili provenienti dall acquisto della collezione Vidovich, ordinate e classificate dal prof. Luigi Stalio. Atti Real. Istit. veneto sci., lett. arti 2, 101-110.

Strobel, P., 1854: Molluschi terrestri raccolti da Cristoforo Bellotti nel 1853 in Dalmazia, con note ed aggiunte di P. Strobel. Giornale di Malacologia 2, 114-123.

Subai, P. \& Neubert, E., 2014: Revision of the genus Lindholmiola Hesse, 1931 (Gastropoda: Pulmonata: Helicodontidae). Contributions to Natural History 23, 1-94.

ŠтAMOL, V., 1986: Contribution to the study of land snails (Gastropoda) of the island of Brač and endargement of endemic species. Biosistematika 12 (1), 45-56. [in Croatian]

ŠтAмоL, V., 2004: Terrestrial snail (Mollusca: Gastropoda terrestria) of the Telašćica Nature Park (Dugi otok, Croatia). Nat. Croat. 13 (2), 95-113.

ŠtamoL, V., 2010: A list of the land snails (Mollusca: Gastropoda) of Croatia, with recommendations for their Croatian names. Nat. Croat. 19 (1), 1-76.

ŠTAMOL, V., 2013: Terrestrial snail (Gastropoda terrestria) of the island of Silba. In: MužINIĆ, J., PuRger, J. J. (eds.): The island of Silba - a natural and cultural treasure. Sveučilište u Zadru, Zadar, p. 103-110. [in Croatia]

ŠTAMOL, V. \& KLETEČKI, E., 2005: Terrestrial snail (Mollusca: Gastropoda terrestria) of Dugi otok (Croatia). Nat. Croat. 14 (1), 1-28.

Štamol, V., KLETeČKI, E. \& Vuković, M., 2012: A contribution to the knowledge of the terrestrial snails (Mollusca: Gastropoda terrestria) of Kornati National Park (Croatia). Nat. Croat. 21 (2), 427-454.

ŠtAmol, V. \& Poje, M., 1998: The fossil and recent malacofauna of the island of Susak (Croatia) (Gastropoda: Prosobranchia, Basommatophora, Stylommatophora). Malak. Abh. Staatl. Mus. Tierk. Dresden 19 (11), 103-117.

Štamol, V., Slapnik, R., Vuković, M. \& KleteČKi, E., 2015: New species of non-marine snails in Croatia (Mollusca: Gastropoda). Nat. Croat. 24 (2), 337-344.

Štamol, V. \& VelKovrh, F., 1995: Contribution to the knowledge of land snail fauna of the islands of Cres and Lošinj (Croatia) (Gastropoda: Prosobranchia, Basommatophora, Stylommatophora). Malak. Abh. Mus. Tierkd. Dresden 17 (20), 219-237.

Westerlund, C. A., 1889: Fauna der in der paläarctischen Region lebenden Binnenconchylien. II. Genus Helix. 473 pp. Håkan Ohlsson's Buchdruckerei, Lund.

Westerlund, C. A., 1890: Katalog der in der paläarctischen Region lebenden Binnenconchylien. 225 pp. + 128 pp. (Register). E. G. Johansson's Buchdruckerei, Karlshamn. 